\title{
SPECIES OF TEREBELLIDES (POLYCHAETA, TEREBELLIDAE, TRICHOBRANCHINAE) FROM THE BRAZILIAN COAST
}

\author{
André R. S. Garraffoni ${ }^{1,2}$ \\ Paulo C. Lana ${ }^{1}$
}

\begin{abstract}
Terebellides sepultura sp. nov. is described from the continental shelf bottoms off southern Brazil. Terebellides carmenensis Solis-Weiss, Fauchald \& Blankensteyn, 1991 is newly recorded for the Brazilian coast and notes on T. anguicomus F. Müller, 1858 and T. klemani Kinberg, 1867 are provided. A key to 28 species of Terebellides is given.
\end{abstract}

KEYWORDS. Trichobranchinae, Terebellides, taxonomy, Brazilian coast.

\section{INTRODUCTION}

The Trichobranchinae, as defined by Rouse \& Pleijel (2001), are tube-dwelling surface deposit feeders, occurring predominantly in soft bottoms of shallow waters (Imajima \& Williams, 1985; Hutchings \& Peart, 2000). This subfamily has five genera: Terebellides Sars, 1835, Artacamella Hartman, 1955, Trichobranchus Malmgren 1866, Unobranchus Hartman, 1965 and Octobranchus Marion \& Bobretzky, 1875. Terebellides, the largest genus, has 34 valid species with worldwide distribution (Holthe, 1986; Hutchings \& Peart, 2000). The genus is diagnosed by having branchiae as a single mid-dorsal stalked structure on segment 3, with four lobes, notochaeta present from segment 3 to 20 and uncini from segment 8 (neurochaeta on segment 8 acicular and distally bent) to the segment before pigidium.

The genus is poorly known in Brazilian waters. NonATO \& LunA (1970) and Solis-WeISS et al. (1991) recorded only three species for the region: T. anguicomus F. Müller, 1858, T. klemani Kinberg, 1867 and T. lanai Solis-Weiss, Fauchald \& Blankensteyn, 1991.

The aim is to present a taxonomic survey of Terebellides species which occur along the Brazilian coast, and a key to the species of the genus.

\footnotetext{
1. Centro de Estudos do Mar, Universidade Federal do Paraná, Caixa Postal 50002, 83255-000, Pontal do Sul, Pontal do Paraná, Paraná, Brazil. (agarraffoni@lycos.com; lana@ufpr.br)

2. Pós-Graduação em Zoologia, Departamento de Zoologia, Universidade Federal do Paraná
} 


\section{MATERIAL AND METHODS}

The study is based on material collected by the REVIZEE program/SCORE SUL, carried out along the southeastern and southern Brazilian continental shelf, and material from Paraná, Rio de Janeiro and Bahia. Samples were taken with a modified van Veen grab (Holme \& McInTyre, 1971) and deposited in the Reference Collection of the Centro de Estudos do Mar, Universidade Federal do Paraná, Pontal do Sul (MCEM) and Instituto de Biologia, Universidade Federal do Rio de Janeiro (UFRJ). The material was identified and described according to Holthe (1986), SolisWeiss et al. (1991), Bremec \& Elias (1999) and Hutchings \& Peart (2000).

Notochaetae were examined on anterior, mid- and posterior thoracic segments. The dental formula of the neurochaetae refers to the number of tooth rows above the main fang (MF) and the number of teeth in each row (MF:3:4 indicates 2 rows of teeth above the main fang, with 3 and 4 teeth per row, respectively).

Key to species of Terebellides

Terebellides pacifica Kinberg, 1867, T. koreni Hansen, 1882, T. ehlersis McIntosh, 1885, T. eurystethus Chamberlin, 1919, T. longicaudatus Hessle, 1917, T. moori Hessle, 1917, and T. williamsae Zirkov, 1988 were not included, since descriptions are poor or inadequate.

1. Presence of a dorsal hump on segment 9 .................................................. 2

No dorsal hump on segment 9 ............................................................... 4

2(1). Seventeen thoracic segments with notopodia; first notopodia on segment

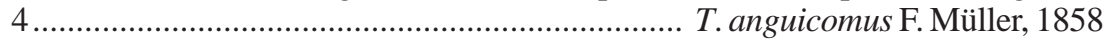

Eighteen thoracic segments with notopodia; first notopodia on segment 3 ..... 3

3(2). Both branchial lobes similar in size, segments 3-7 with lateral lappets ...............

T. totae Bremec \& Elias, 1999

Ventral branchial lobe slender than dorsal, segments 3-5 with lateral lappets .....

T. carmenensis Solis-Weiss, Fauchald \& Blankensteyn, 1991

4(1). Branchial lobes free for $2 / 3$ of their length ................................................... 5

Branchial lobes fused for up to half their length .......................................... 6

5(4). Five lobed branchiae, lateral lappets on segments 3-5 .................................

Four lobed branchiae, lateral lappets on segments 3-7 ...... T. sepultura sp. nov.

6(4). Notopodia from segment 3 larger than posterior ones ................................... 7

Notopodia from segment 3 shorter or as long as posterior ones ..................... 8

7(6). Posterior region of the lobes 1 and 2 with papillar projection ..........................

Posterior region of the lobes 1 and 2 without papillar projection

T. kobei Hessle, 1917

8(6). Posterior region of the lobes 1 and 2 with papillar projections ........................ 9

Posterior region of the lobes 1 and 2 without papillar projections .................. 14

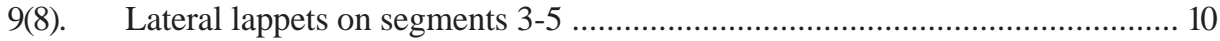

Lateral lappets on segments $3-7$........................................................ 12

10(9). Four lobed branchiae ............................................... T. reishi Williams, 1984

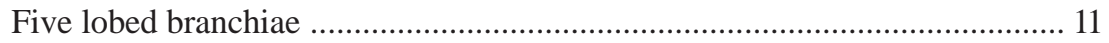

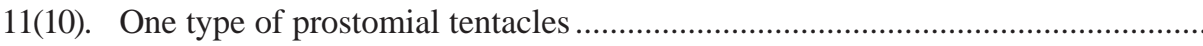

T. lanai Solis-Weiss, Fauchald \& Blankensteyn, 1991

Iheringia, Sér. Zool., Porto Alegre, 93(4):355-363, 30 de dezembro de 2003 
Two types of prostomial tentacles T. woolawa Hutchings \& Peart, 2000

12(9). Four lobed branchiae T. kowinka Hutchings \& Peart, 2000 Five lobed branchiae 13

13(12). Nephridial papilae on segments 3, 6-7 ....... T. narribri Hutchings \& Peart, 2000 Nephridial papilae on segment 3

T. parvus Solis-Weiss, Fauchald \& Blankensteyn, 1991

14(8). Acicular uncini on segments 8 and 9.......... T. intoshi Imajima \& Williams, 1985

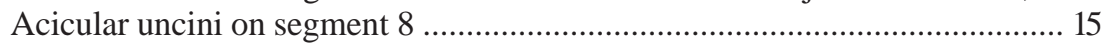

15(14). Acicular uncini with an unusual sheath covering tip ...................................... 16

Acicular uncini without an unusual sheath covering tip ................................ 17

16(15). Branchial lobes free for $2 / 3$ of their length, 34-39 abdominal segments ............T. distincta Williams, 1984

Branchial lobes fused for up to half their length, 45-50 abdominal segments ..... T.japonica (Moore, 1903)

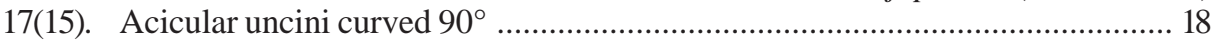

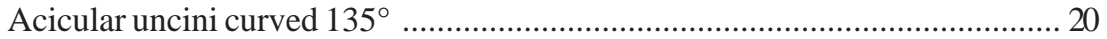

18(17). Acicular uncini with mucronate tips .............. T. brevis Imajima \& Williams, 1985

Acicular uncini without mucronate tips ......................................................... 19

19(18). Anterior notopodia inserted more dorsally compared to posterior ones, notopodia from segment 3 as long as posterior ones .................. T. atlantis Williams, 1984 Anterior notopodia inserted in line compared to posterior ones; notopodia from segment 3 shorter than posterior ones T. biaciculata Hartmann-Schröder, 1992

20(17). Segment 3 with conspicuous projection at the level of the notopodia

Segment 3 without conspicuous projection at the level of the notopodia ...... 21

21(20). Branchial lobes free for $2 / 3$ of their length ................................................ 22

Branchial lobes fused for up to half of their length ......................................... 25

22(21). Dorsal branchial lobes much larger than ventral ones ..................................... 23

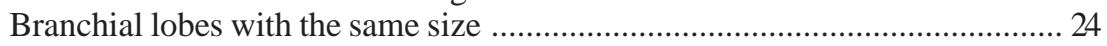

23(22). Lateral lappets on segments 5 and 6 well developed, acicular uncini curved $135^{\circ}$ T. lobatus Hartman \& Fauchald, 1971 Lateral lappets on segments 4 and 5 well developed, acicular uncini curved $90^{\circ}$ T. malvinensis Bremec \& Elias, 1999

24(22). Ventrum of segment 6 with a light band, notopodia from segment 3 shorter than posterior ones ............................................ T. lineata Imajima \& Williams, 1985 Ventrum of segment 6 without a light band, notopodia from segment 3 as long as posterior ones ......................................... T. mundora Hutchings \& Peart, 2000

25(21). Notopodia from segment 3 as long as posterior ones ....... T. stroemii Sars, 1835 Notopodia from segment 3 shorter or as long as posterior ones .................... 26

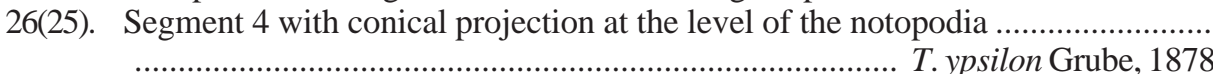
Segment 4 without conical projection at the level of the notopodia ................ 27

27(26). Lateral lappets on segments 3-7 ............ T. horikoshii Imajima \& Williams, 1985 Lateral lappets on segments 3-5 ................ T. bisetosa Hartmann-Schröder, 1965 


\section{Terebellides sepultura sp. nov.}

(Figs. 1-8)

Etimology. The species is named to honour Sepultura, the best Brazilian heavy metal band.

Diagnosis. Eighteen thoracic segments with notopodia, first notopodia on segment 3 . Branchial lobes free for $2 / 3$ of their length. Branchiae four-lobed, with numerous tentacles of similar width.

Buccal tentacles of one type, with expanded tips. Prostomium compact, fused to the peristomial free frontal edge, tentacular membrane compact. Peristomial upper lip hidden, expanded lower lip as an elongate rectangular structure (fig. 1). Eyespots absent. Lateral lappets present on segment 3, distinctly reduced on segments 4 to 7 . Nephridial papillae not visible.

Branchiae as a single mid-dorsal stalked structure on segment 3, with four lobes, two large and two small ones, fused basally, made up of loosely fused flat lamellae (fig. 2).

Notopodia 18 pairs, present on segment 3-20. First pair (on segment 3) less developed than posterior ones, with small capillary notosetae. Anterior notopodia laterally inserted, at same level of those from subsequent chaetigers. Neuropodia present from segment 8 to segment before pygidium.

Notochaetae on segment 3 small, reduced in length and number in comparison to notochaetae of the posterior notopodia. Notochaetae similar in structure belonging to two kinds: with single or double wings (fig. 3).

Neuropodial uncini always in a single row. First thoracic neuropodia with 5 retractile distally pointed acicular spines, on segment 8 (chaetiger 6) (fig. 4). Following thoracic neuropodia with long-shafted hooks with dental formula MF:5:4 (figs. 5, 6). Thoracic neuropodia, except for the first, with 5 to 6 uncini per torus; abdominal uncini breviavicular with a dental formula of MF:4-5:5-6, 14-18 per tori (figs. 7, 8). Subrostral process absent.

Segments crowded towards posterior end of the body. Pygidium short and conical. Anus terminal; without blunt papillae. No tube was observed.

Variation. One examined specimen (MCEM 1630) has only one branchial lobe. As previously suggested by HutChIngs \& PEART (2000) for other trichobranchin species, this variation may be a result of lobes being damaged and becoming detached.

Remarks. Terebellides sepultura resembles $T$. klemani in having branchiae lobes free for $2 / 3$ of their length (figs. 1,3). Terebellides sepultura can be distinguished by the presence of lateral lappets on segments 3-7, four branchiae lobes, a lower number of thoracic uncini per segment, and a single mid-dorsal branchial stalked structure (length up to 1.5 - 2 segments) much larger than in congeneric species (length up to 0.5 - 1 segment) (tabs. I, II).

Biological data. Occurs in continental shelf bottoms, between 163 and $350 \mathrm{~m}$ in depth, on muddy sediments.

Type material. Holotype: off southern Brazilian coast, station $6784,27^{\circ} 9.51^{\prime} \mathrm{S}, 47^{\circ} 4.85^{\prime} \mathrm{W}$, $195 \mathrm{~m}$, specimen complete (MCEM 1623). Paratypes: all off southern Brazilian coast, station $6787,27^{\circ} 27.83^{\prime} \mathrm{S}, 47^{\circ} 24.22^{\prime} \mathrm{W}, 151 \mathrm{~m}$ (MCEM 1624); station $6822,29^{\circ} 48.5^{\prime} \mathrm{S}, 49^{\circ} 6.80^{\prime} \mathrm{W}, 103$

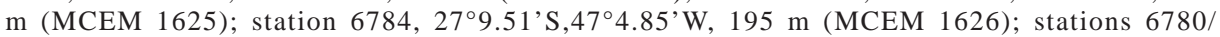


6797, $27^{\circ} 7.00^{\prime} \mathrm{S}, 47^{\circ} 44.2^{\prime} \mathrm{W}, 102 \mathrm{~m}$ (MCEM 1627); station 6666, 24 ${ }^{\circ} 17.129^{\prime} \mathrm{S}, 4^{\circ} 12.149^{\prime} \mathrm{W}$, $163 \mathrm{~m}$ (MCEM 1628); specimens without abdominal part: station $6783,27^{\circ} 9.90^{\prime} \mathrm{S}, 46^{\circ} 52.83^{\prime} \mathrm{W}$,

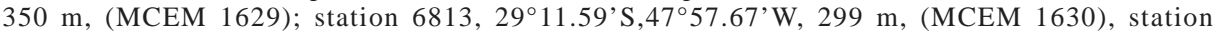
$6666,24^{\circ} 17.129^{\prime} \mathrm{S}, 47^{\circ} 12,149^{\prime} \mathrm{W}, 163 \mathrm{~m}$, (MCEM-1631); station $6784,27^{\circ} 9.51^{\prime} \mathrm{S}, 47^{\circ} 4.85^{\prime} \mathrm{W}$, $195 \mathrm{~m}$, specimen broken in three parts (MCEM 1632).

Table I. Characters of species of Terebellides from the Gulf of Mexico and from Brazilian and Argentinean coasts.

\begin{tabular}{|c|c|c|c|c|c|c|}
\hline Species & $\begin{array}{l}\text { Nephridial } \\
\text { papillae }\end{array}$ & Hump & $\begin{array}{c}\text { Chaetigers } \\
\text { with lateral } \\
\text { lappets }\end{array}$ & $\begin{array}{c}\text { Dorsal and } \\
\text { ventral branchiae } \\
\text { lobes }\end{array}$ & $\begin{array}{l}\mathrm{N}^{\circ} \\
\text { lobes }\end{array}$ & $\begin{array}{c}\text { Acicula shape on } \\
\text { seg. } 8\end{array}$ \\
\hline T. anguicomus & Present & $\underset{9}{\text { Segment }}$ & $1-6$ & $\begin{array}{l}\text { Both lobes } \\
\text { similar in size }\end{array}$ & 5 & $\begin{array}{l}\text { Sharply bent, } \\
\text { pointed tip }\end{array}$ \\
\hline T. carmenensis & Present & $\begin{array}{c}\text { Segment } \\
9\end{array}$ & $1-5$ & $\begin{array}{c}\text { V. lobe slender } \\
\text { than } \mathrm{d} .\end{array}$ & 5 & $\begin{array}{c}\text { Gently curved, } \\
\text { acute tip }\end{array}$ \\
\hline T. klemani & Present & Absent & $1-3$ & $\begin{array}{l}\text { Both lobes } \\
\text { similar in size }\end{array}$ & 5 & $\begin{array}{l}\text { Gently curved, } \\
\text { acute tip }\end{array}$ \\
\hline T. lanai & Present & Absent & $1-8$ & $\begin{array}{l}\text { V. lobe slender } \\
\text { than } \mathrm{d} \text {. }\end{array}$ & 5 & $\begin{array}{l}\text { Sharply bent, } \\
\text { pointed tip }\end{array}$ \\
\hline T. malvinensis & $?$ & Absent & $1-5$ & $\begin{array}{l}\text { V. lobe slender } \\
\text { than } \mathrm{d} \text {. }\end{array}$ & 5 & $\begin{array}{l}\text { Sharply bent, } \\
\text { pointed tip }\end{array}$ \\
\hline T. parvus & Present & Absent & $?$ & $\begin{array}{c}\text { Both lobes } \\
\text { similar in size }\end{array}$ & 5 & $\begin{array}{l}\text { Sharply bent, } \\
\text { pointed tip }\end{array}$ \\
\hline T. totae & $?$ & $\begin{array}{c}\text { Segment } \\
9\end{array}$ & $1-6$ & $\begin{array}{l}\text { Both lobes } \\
\text { similar in size }\end{array}$ & 5 & $\begin{array}{c}\text { Gently curved, } \\
\text { acute tip }\end{array}$ \\
\hline T. sepultura & Not visible & Absent & $1-5$ & $\begin{array}{c}\text { V. lobe slender } \\
\text { than } \mathrm{d} .\end{array}$ & 4 & $\begin{array}{l}\text { Sharply bent, } \\
\text { pointed tip }\end{array}$ \\
\hline
\end{tabular}

\section{Terebellides carmenensis Solis-Weiss, Fauchald \& Blankensteyn, 1991}

(Figs. 9, 10)

Terebellides carmenensis Solis-Weiss et al., 1991:151, fig. 1j-m; Hutchings \& Peart 2000:244, 248, tabs. 3a, b.

Terebellides klemani; Hernández-Alcantara \& Solis-Weiss, 1991:457, tab.2.

Remarks. The specimens analyzed in this study closely resemble the original description provided by Solis-WeIss et al. (1991). Their main diagnostic features are the presence of a dorsal hump on segment 9 , notopodia of segment 3 smaller than posterior ones, acicular uncini on segment 8 (chaetiger 6) sharply bent and with a pointed tip, and branchial lobes fused for most of their length. Specimens from the Brazilian coast differ from the original description of Terebellides carmenensis only in number of thoracic and abdominal neurochaetae. Solis-WeIss et al. (1991) described 12 thoracic long-handled neurochaetae and 45-48 abdominal neurochaetae in the holotype (39-54 in the paratypes), whereas specimens from the northeastern Brazilian coast have 10-12 thoracic neurochaetae with long-handled hooks and 25-35 abdominal neurochaetae (figs. 9, 10), most probably as a result of intraspecific variation. This species is new to the Brazilian marine fauna.

Biological data. In shallow waters associated with mangrove vegetation (SolisWeIss et al., 1991), and coral reefs. 
Distribution. Isla de Carmen, Campeche (Mexico); Recife das Paredes, and Recife da Lixa, Bahia State (Brazil).

Material examined. BRAZIL, Bahia: 2 specimens, $17^{\circ} 59.763^{\prime}$ 'S, $39^{\circ} 16.356^{\prime} \mathrm{W}, 5$ a $9 \mathrm{~m}$, 19.II.2000, P. C. Paiva col. (UFRJ 331); 2 specimens, $17^{\circ} 45.127^{\prime} \mathrm{S}, 38^{\circ} 58.720^{\prime} \mathrm{W}, 8 \mathrm{~m}$, 25.II.2000, P. C. Paiva col. (UFRJ 332).

Table II. Characters of species of Terebellides from the Gulf of Mexico and from Brazilian and Argentinean coasts. References: (1) Solis-Weiss et al. (1991); (2) Bremec \& Elias (1999).

\begin{tabular}{|c|c|c|c|c|c|c|}
\hline Species & $\begin{array}{l}\text { Notopodia } \\
\text { on seg. } 3\end{array}$ & $\begin{array}{c}\mathrm{N}^{\circ} \\
\text { thoracic } \\
\text { uncini } \\
\text { per torus }\end{array}$ & $\begin{array}{l}\mathrm{N}^{\circ} \text { teeth } \\
\text { rows in } \\
\text { abdominal } \\
\text { uncini }\end{array}$ & $\begin{array}{l}\mathrm{N}^{\circ} \\
\text { abdominal } \\
\text { uncini per } \\
\text { torus }\end{array}$ & $\begin{array}{l}\mathrm{N}^{\circ} \\
\text { abdominal } \\
\text { chaetigers }\end{array}$ & $\begin{array}{l}\text { Type locality, depth } \\
\text { and reference }\end{array}$ \\
\hline T. anguicomus & Absent & $6-8$ & 2 & $19-49$ & $40-42$ & $\begin{array}{c}\text { Paranaguá Bay, } \\
25^{\circ} 29^{\prime} 48^{\prime} \mathrm{S}, \\
48^{\circ} 29^{\prime} 30^{\prime} \mathrm{W}, 16 \mathrm{~m}(1)\end{array}$ \\
\hline T. carmenensis & $\begin{array}{l}\text { Smaller } \\
\text { than } \\
\text { posterior }\end{array}$ & 12 & $?$ & $39-54$ & 37 & $\begin{array}{l}\text { San Julian, Isla de } \\
\text { Carmen, Mexico, } \\
\text { intertidal (1) }\end{array}$ \\
\hline T. klemani & $\begin{array}{l}\text { Smaller } \\
\text { than } \\
\text { posterior }\end{array}$ & $10-14$ & $?$ & 35 & $30-32$ & $\begin{array}{c}\text { Atlantic Ocean } \\
22^{\circ} 30^{\prime} \mathrm{S}, \\
40^{\circ} 55^{\prime} \mathrm{W}, 36-73 \mathrm{~m}(1)\end{array}$ \\
\hline T. lanai & $\begin{array}{l}\text { Smaller } \\
\text { than } \\
\text { posterior }\end{array}$ & $8-10$ & 3 & $25-29$ & 38 & $\begin{array}{c}\text { Brasilian coast } 24^{\circ} 16^{\prime} \mathrm{S}, \\
46^{\circ} 01^{\prime} 02^{\prime} \mathrm{W}, 45 \mathrm{~m} \\
\text { (1) }\end{array}$ \\
\hline T. malvinensis & $\begin{array}{l}\text { Similar } \\
\text { than } \\
\text { posterior }\end{array}$ & $9-10$ & $?$ & 40 & $?$ & $\begin{array}{c}\text { Argentinean coast } \\
38^{\circ} 44^{\prime} \mathrm{S}, 56^{\circ} 13^{\prime} \mathrm{W}, 87 \mathrm{~m} \\
\text { (2) }\end{array}$ \\
\hline T. parvus & $\begin{array}{l}\text { Smaller } \\
\text { than } \\
\text { posterior }\end{array}$ & 12 & 2 & $18-37$ & 25 & $\begin{array}{c}\text { West Bay, Twin Cays, } \\
\text { Belize, } 10-50 \mathrm{~m} \\
\text { (1) }\end{array}$ \\
\hline T. totae & $\begin{array}{l}\text { Smaller } \\
\text { than } \\
\text { posterior }\end{array}$ & $8-17$ & $?$ & $\begin{array}{l}23-27 / \\
59-72\end{array}$ & 39 & $\begin{array}{c}\text { Blanca Bay, Argentina, } \\
38^{\circ} 54^{\prime} 00^{\prime \prime} \mathrm{S}, 62^{\circ} 11^{\prime} 50^{\prime \prime} \mathrm{W}, \\
20 \mathrm{~m}(2)\end{array}$ \\
\hline T. sepultura & $\begin{array}{l}\text { Smaller } \\
\text { than } \\
\text { posterior }\end{array}$ & $5-6$ & 2 & $14-17$ & $28-29$ & $\begin{array}{c}\text { off southern Brazilian } \\
\text { coast, } 27^{\circ} 9.51^{\prime} \mathrm{S} \\
47^{\circ} 4.85^{\prime} \mathrm{W}, 195 \mathrm{~m}\end{array}$ \\
\hline
\end{tabular}

\section{Terebellides anguicomus F. Müller, 1858}

(Figs. 11, 12)

Terebellides anguicomus MüLleR, 1858:218, pl. 7, figs. 22-25; Hessle, 1917:141, fig. 33a-c (in part); Nonato \& Luna, 1970:97; Solis-Weiss et al., 1991:149, figs. 1g-i; Hutchings \& Peart, 2000:244, table 3a, b.

Remarks. The examined specimens closely resemble the neotype designated by Solis-Weiss et al. (1991) (United State Nacional Museum 131996), collected in Paraná State. These authors stated that the species has a "dorsum with a large, transversely oriented hump on setiger 5". In the present specimens and in the illustration of the neotype description (Solis-WeIss et al., 1991:150, fig. 1g) a dorsal hump is clearly present on segment 9 (chaetiger 7), probably on account of a 

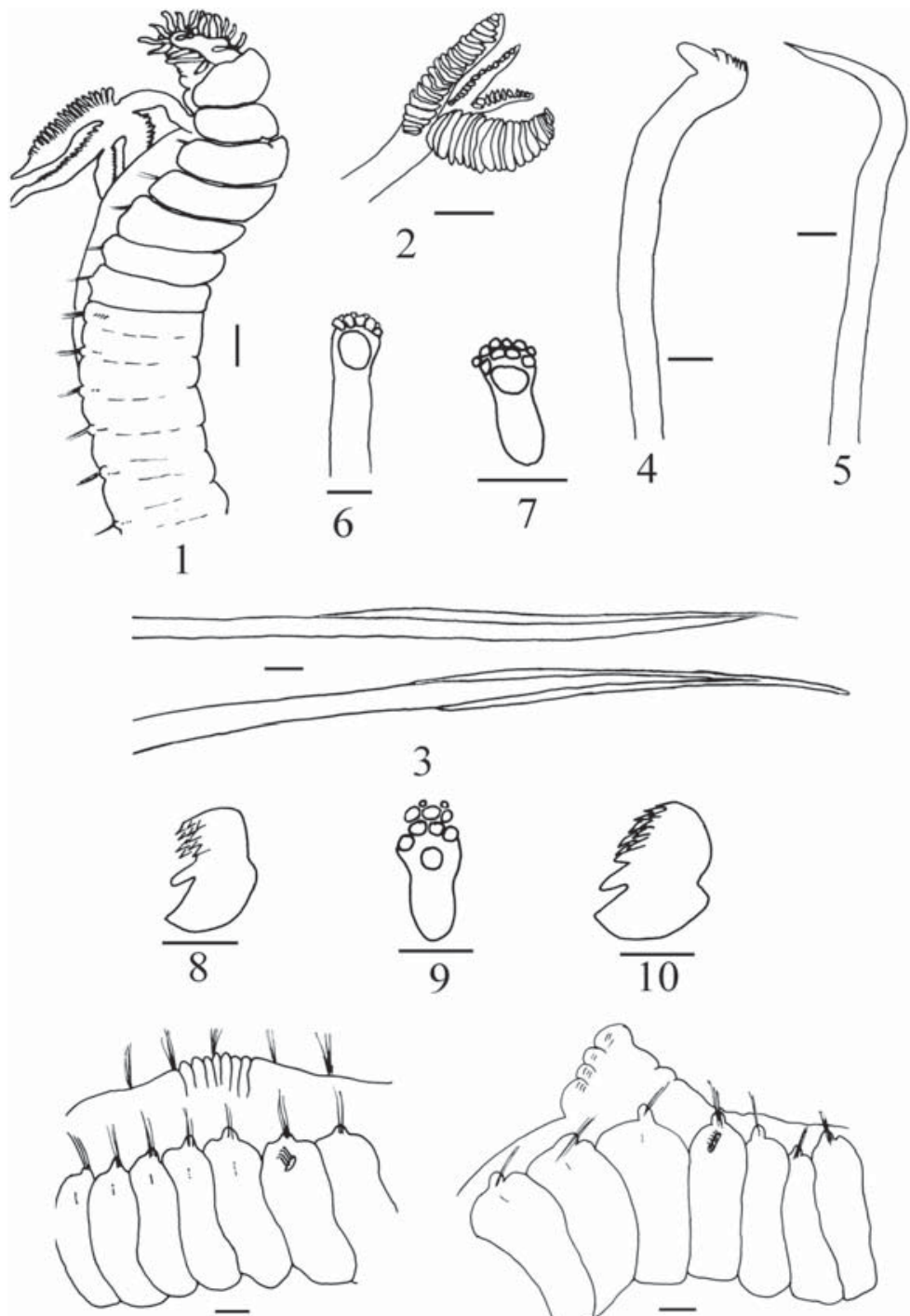

11

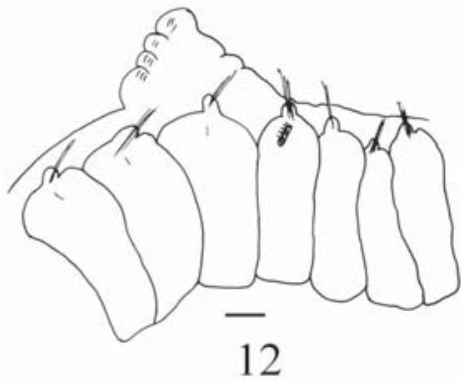

Figs. 1-12. Terebellides sepultura sp. nov.: 1, anterior part of body, lateral view (holotype, MCEM 1623); 2, branchia with 4 lobes, ventral. Paratype, MCEM 1632: 3, two kinds of notochaeta from the anterior part of thorax of the same segment; 4 , thoracic neurochaeta, lateral; 5, thoracic neurochaeta, frontal; 6 , neurochaeta on segment $8 ; 7$, 8, abdominal uncinus: 7, lateral; 8, frontal. T. carmenensis Solis-Weiss, Fauchald \& Blankensteyn, 1991: 9, abdominal uncinus, frontal view; 10, abdominal uncinus, lateral view. T. anguicomus F. Müller, 1858: 11, lateral view of anterior part of dead specimen; 12, lateral view of anterior part of alive specimen. Scale bars: figs. $1,2,11,12,0.2 \mathrm{~mm} ; 3-5,7-10,9 \mu \mathrm{m} ; 6,22.2 \mu \mathrm{m}$. 
misunderstanding of the numbering of anterior segments, which then modifies the notation of all subsequent segments. We had the opportunity to examine live specimens and to check that the size of this dorsal hump can vary between live and fixed specimens (figs. 11,12). The three species that present the dorsal hump, Terebellides anguicomus, T. carmenensis and T. totae, have this structure on segment 9 (chaetiger 7). Solis-Weiss et al. (1991) also stated that "the nephridial papillae are in a groove medial to rudimentary parapodia of segment 2, close to branchial base". The specimens studied herein have nephridial papillae on segment 3, the same segment of the branchial base. reefs.

Biological data. In shallow waters on silty and sandy sediments and coral

Distribution. Brazil: from Sergipe to Santa Catarina states.

Material examined. BRAZIL, Bahia: Recife da Lixa, 2 specimens, $17^{\circ} 45.127^{\prime}$ S, $38^{\circ} 58.720^{\prime}$ W, 8m, 25.II.2000, P. C. Paiva col. (UFRJ 334); Recife das Paredes, 2 specimens, $17^{\circ} 59.763^{\prime}$ S, $39^{\circ} 16.356^{\prime}$ W, 5 a $9 \mathrm{~m}$ 19.II.2000, P. C. Paiva col. (UFRJ 335). Paraná, Baia de Paranguá, 4 specimens, 09.I.86, Blankensteyn col. (MCEM 328).

\section{Terebellides klemani Kinberg, 1867}

Terebellides klemani Kinberg, 1867:346; Hartman, 1948:14; Solis-Weiss et al., 1991: 148, figs. 1a-f; Hutchings \& Peart, 2000:244, 248, tabs. 3a, b.

Terebellides anguicomus; Hessle, 1917:141, figs. 33a-c (in part, not T. anguicomus MülLer, $1858)$.

Remarks. Terebellides klemani was synonymized with T. anguicomus by HesSLE (1917). The two species are currently considered valid (Solis-WeIss et al., 1991). Terebellides klemani differs from $T$. anguicomus by the absence of a dorsal hump on segment 9, notopodia on segment 3, and free branchial lobes. The animals collected in this study closely agree with the description provided by SoLIS-WeIss et al. (1991).

Biological data. In shallow waters on muddy or sandy sediments (SoLIs-WeIss et al., 1991) and coral reefs.

Distribution. Brazil: from Alagoas to Santa Catarina states.

Material examined. BRAZIL, Bahia: 4 specimens, $17^{\circ} 45.127^{\prime} \mathrm{S}, 38^{\circ} 58.720^{\prime} \mathrm{W}, 8 \mathrm{~m}$, 25.II.2000, P. C. Paiva col. (UFRJ 333).

Acknowledgements. To Cecília Amaral (UNICAMP) for the loan of REVIZEE material, Paulo César Paiva for lending material from Instituto de Biologia (UFRJ). Cinthya Gomes (UFPR) and Mary Petersen (Zoological Museum, University of Copenhagen) provided useful critical comments.

\section{REFERENCES}

Bremec, C. S. \& Elias, R. 1999. Species of Terebellides from South Atlantic waters off Argentina and Brazil (Polychaeta: Trichobranchidae). Ophelia, Elsinore, 51(3):177-186.

Hartman, O. 1948. The marine annelids erected by Kinberg, with some notes on some other types in the Swedish State Museum. Ark. Zool., Stockholm, 42:1-137.

Hernández-Alcantara, P. \& Solis-Weiss, V. 1991. Ecological aspects of the polychaete populations associated to the red mangrove Rhizophora mangle at Laguna de Terminos, southeastern part of Gulf of Mexico. Ophelia, Elsinore, 5 (Suppl):451-462. 
Hessle, C. 1917. Zur kenntnis der Terebellomorphen Polychaeten. Zool. Bidr. Upps., Stockholm, 5:39-258.

Holme, N. A \& McIntyre, A. D. 1971. Methods for the study of marine benthos. 1. ed. Oxford, Blackwell Scientific. 334p.

Holthe, T. 1986. Evolution, systematics and distribution of the Polychaeta Terebellomorpha, with a catalogue of the taxa and a bibliography. Gunneria, Trondheim, 55:1-236.

Hutchings, P. A \& Peart, R. 2000. A revision of the Australian Trichobranchidae. Invertebr. Taxon., Collingwood, 14:225-272.

Imajima, M. \& Williams, S. J. 1985. Trichobranchidae (Polychaeta) chiefly from the Sagami and Suruga Bays, collected by R/V Tansei Maru (Cruises KT-65-76). Bull. natn. Sci. Mus, Series A, Tokyo, 11(1):7-18.

Kinberg, J. C. H. 1867. Annulata nova. Öfvers. K. VetenskAkad. Förh., Stockholm, 23(9):337-357.

MüLleR, F. 1858. Einiges uber die Annelidenfauna der Insel Santa Catharina an der Brasilianischen Kuste. Arch. Naturgesch., Berlin, 24:211-220.

Nonato, E. \& Luna, J. A. 1970. Anelídeos poliquetas do nordeste do Brasil. I. Poliquetas bentônicos da costa de Alagoas e Sergipe. Bolm Inst. Oceanogr. S. Paulo, São Paulo, 19(299):57-130.

Rouse, G. W. \& Pleijel, P. 2001. Polychaetes. London, Oxford. 354p.

Solis-Weiss, V.; Fauchald, K. \& Blankensteyn, A. 1991. Trichobranchidae (Polychaeta) from shallow warm water areas in the Western Atlantic Ocean. Proc. Biol. Soc. Wash., Washington, 104(1): $147-158$. 